\title{
CONFERENCE OF RECTORS OF UNIVERSITES OF BALKAN COUNTRIES CONFERENCE DES RECTEURS DES UNIVERSITES DES PAYS BALCANIQUES
}

c/o Bogaziçi Universitesi

80815 Bebek

Istanbul (Turkey)

Tel: (1) 165-1486

Chairman: Prof. Dr. Ergün Togrol, Rector,

Bogaziçi Universitesi

The first Conference of Rectors of Universities of Balkan Countries took place in Belgrade from 11 to 14 November 1982, following a recommendation made by the Ninth Conference of National Commissions of Unesco in the Balkan Countries. The purpose is to strengthen co-operation between universities in the region and between them and the Unesco European Centre for Higher Education (CEPES). Its members are the Rectors of the Universities and University Institutions in
Bulgaria, Greece, Romania, Turkey and Yougoslavia.

A la suite d' une recommandation formulée par la Neuvième Conférence des Commissions Nationales de l'Unesco dans les pays balcaniques, la première Conférence des Recteurs des Universités des Pays Balcaniques s'est tenue à Belgrade, du 11 au 14 Novembre 1982. L'objet de la Conférence est de renforcer la coopération des universités de la région aussi bien entre elles qu'avec le Centre Européen pour l'Enseignement supérieur (CEPES) de l'Unesco. Elle se compose des recteurs des universités et des institutions universitaires de Bulgarie, de Grèce, de Roumanie, de Turquie et de Yougoslavie. 